
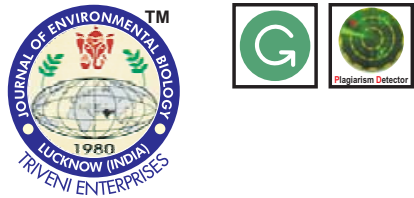

DOI : http://doi.org/10.22438/jeb/38/6/MS-242

\title{
Studies on crossing behaviour and hybridization in guava
}

ISSN: 0254-8704 (Print) ISSN: 2394-0379 (Online) CODEN: JEBIDP

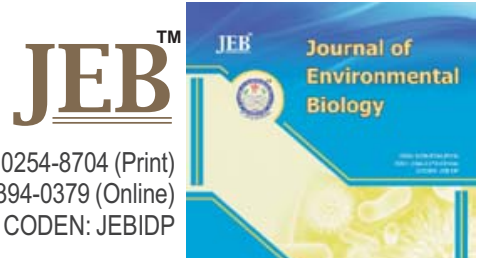

\section{Authors Info}

\section{Singh*, M.I.S. Gill and N.K. Arora}

Department of Fruit Science, Punjab Agricultural University Ludhiana-141 004, India

*Corresponding Author Email : dharmendrachoudhary32@gmail.com

Key words

Anthocyanin

Crossing behaviour

Guava cultivars

Hybridization

Seed hardness

Publication Info

Paper received : 09.01.2016

Revised received : 12.06 .2016

Re-revised received : 27.10 .2016

Accepted : 22.12.2016

\section{Abstract}

Aim: The commercial guava cultivars though having high yield potential, lack the traits of commerce. In other words, development of high yielding guava variety having coloured skin and flesh, with low seed content/soft seeds and better shelf life is need of an hour.

Methodology: The present study on hybridization was undertaken using commercial varieties like Allahabad Safeda, Shweta and the varieties with potential traits like Arka Kiran, Purple guava and Lalit.

Results: Among different crosses, the maximum fruit length $(51.25 \mathrm{~mm})$, fruit width $(48.70 \mathrm{~mm})$ and fruit weight $(71.84 \mathrm{~g})$ were recorded in Allahabad Safeda x Shweta. The lowest number of seeds per fruit (171), minimum seed weight per fruit $(1.070 \mathrm{~g})$, seed hardness $\left(13.86 \mathrm{Kg} \mathrm{cm}^{-2}\right)$ and highest total soluble solids (7.45 ${ }^{\circ}$ Brix) were recorded in Allahabad Safeda x Arka Kiran, whereas, the Allahabad Safeda x Purple guava fruits had significantly higher vitamin C (180.14 mg per $100 \mathrm{~g}$ fruit) content.

Interpretation: To conclude, the optimum time of crossing involving potential guava germplasm has been standardized. Sufficient number of hybrids as a result of different cross combinations have been obtained, which are likely to have potential traits.

Studies on crossing behaviour and hybridization among different guava genotypes/varieties

Allahabad Safeda (female parent) was crossed with different guava varieties namely Lalit, Purple guava, Arka Kiran and Shweta (male parent)

50 flower buds per cross combination all around the trees were randomly selected, tagged, emasculated, bagged on healthy and uniform trees of AllahabadSafeda.

ए

Morphological characters of guava accessions wererecorded on basis of UPOV (International Union for the Protection of New Varieties of Plants) descriptors.

Physico-chemical attributes such as Total soluble solids, titratable acidity, Vitamin $C$ and pectin content were recorded.

The obtained hybrid seedlings were planted in the field.

The putative hybrids thus generated have shown the variability in morphological traits and indicate hybridity. 


\section{Introduction}

Guava fruit is commonly designated as 'apple of the tropics'. It belongs to family Myrtaceae which comprises about 150 genera and more than 5,650 species. Floral structure (Epigynous flower, with many stamens of various sizes), selfincompatibility, and heterozygous nature limit the scope of breeding programmes of guava. Germplasm across the genera and species are being used for hybridization studies. Distant hybridization involves crosses between different species of the same genus or different genera. Santos et al. (2012) observed that pink and red guava accessions have a greater beneficial potential and should be targeted for breeding programs. Being a cross-pollinated species, substantial variability is available in guava propagated through seeds.

There are a large number of cultivars in India, but only a few with commercial importance such as 'Allahabad Safeda' and L-49 (Sardar) have been identified for commercial cultivation; however, this fact does not affect the existence of a large number of breeding programs. For example techniques such as interspecific crosses (Dinesh et al., 2010a) and induced mutation have been used to bring variability in guava (Pommer, 2012). Inter-specific hybridization between Psidium molle and P. guajava has led to the development of hybrids (Negi et al., 2007). Seedless varieties of guava have been found to be autotriploids $(2 n=33)$; likewise, hybridization between $P$. guajava and $P$. guineense has also been reported (Landrum et al., 1995). Elite commercial guava cultivars, round and pyriformed, were reciprocally crossed to develop hybrids and fruits after crossing were analyzed to explore metaxenial effects on fruit quality (Usman et al., 2013). The present study on inter-varietal hybridization was thus planned involving varieties with coloured skin, flesh and less seed content.

\section{Materials and Methods}

Morphological characters of guava accessions were observed on the basis of UPOV (International Union for the Protection of New Varieties of Plants) descriptors (Rodriguez et al 2010). Hybridization and crossing behaviour of guava cultivar Allahabad Safeda (female parent) was assessed with different varieties; Lalit, Purple Guava, Arka Kiran and Shweta (male parent) of guava i.e., with coloured skin, coloured flesh and low/soft seeds. Randomly selected fifty flower buds per combinationall around the trees were tagged, emasculated, bagged on healthy and uniform trees of Allahabad Safeda. For observing the time of anthesis, flower buds expected to open the next day were tagged on the previous evening and the number of fully opened flowers were noted at an interval of one hour (starting from 4:30 a.m. in the next morning). To determine the pollen germination, $0.08 \%$ agar-solidified medium and $10 \%$ sucrose solution were used and observed for pollen grains germination within 16-48 hrs. The number of fruits which had set on tagged flowers were recorded after initial stage of fruit development and number of fruits retained on each tagged flower were counted a week before harvesting. The length and width of mature fruits were measured with the help of digital vernier caliper (Mitutoyo Inc., Japan). The weight of mature fruits, seed weight per fruit and hundred seed weight were recorded with a pan balance and expressed in grams. Extracted seeds from each fruit was counted manually and average was calculated and expressed as number of seeds per fruit. Seed size in each variety was observed visually and expressed under small, medium and bold categories. Seed hardness was measured with the help of hardness tester which showed the hardness of seeds in $\mathrm{kg} \mathrm{cm}^{-2}$, whereas, the colour of fruit and flesh was estimated visually. Total soluble solid content of juice was measured with the help of digital hand refractrometer. Acidity was estimated by titrating a known volume of juice against $\mathrm{N} / 10$ Sodium hydroxide $(\mathrm{NaOH})$ using phenolphthalein as an indicator. Vitamin C content was measured with 2,6dichlorophenol indophenol dye (AOAC, 2005). Pectin content as percent calcium pectate per $100 \mathrm{~g}$ pulp was estimated using gravimetric method. Seed germination percentage of different $F_{1}$ hybrids viz. Allahabad Safeda x Lalit, Allahabad Safeda x Purple Guava, Allahabad Safeda x Arka Kiran and Allahabad Safeda x Shweta were recorded. Young shoot characters were observed at the time of emergence, whereas mature leaf characters were observed during growing season. The colour of young twigs was observed visually and categorized as green and red. Similarly, presence or absence of anthocyanin colouration for fresh leaves were observed visually. The petiole length, leaf blade length and width of ten randomly selected mature leaves were measured with the help of digital vernier caliper (Mitutoyo Inc., Japan). The results obtained during both the years of study (2014-15) were subjected to analysis of variance using RBD design, and the treatment means were compared using least significant difference (LSD) values at a significance level of $P \leq 0.05$ using the procedures of Statistical Analysis System 9.3.

\section{Results and Discussion}

Variability in guava varieties for morphological traits: The peak period of anthesis in guava varieties (Allahabad Safeda, Lalit, Arka Kiran, Purple Guava and Shweta) was observed from 6.30 to 8.30 a.m. during rainy season. Similarly, Dhaliwal et al. (2002) observed peak period of anthesis and dehiscence from 6.30 to 8.30 a.m. in Bangalore Seedling Selections (6/10, 6/12, 17/7), Sardar Seedling Selections (4/10, 4/12, 6/8), Hisar Surkha, Hisar Sufeda, Dharwad and Sardar. Pollen is an important vector of gene flow in plants particularly for out crossing species. The highest pollen germination of $87.33 \%$ was observed in Allahabad Safeda followed by Lalit (85.30\%), Shweta (85.16 \%), Purple Guava (83.59 \%) and Arka Kiran (72.35\%). Allahabad Safeda, Shweta, Lalit and Purple Guava varieties had no significant difference between them but these were significantly different from Arka Kiran (Table 1). Likewise, germination of pollen tube 
was tested (Coseret al., 2012) earlier in different guava varieties using staining techniques.

The maximum fruit set $(61.22 \%)$ was recorded in Allahabad Safeda $x$ Lalit, followed by Allahabad Safeda x Shweta (55.56 \%) and Allahabad Safeda x Purple Guava (54.16\%), while minimum fruit set $(45.83 \%)$ was observed in crossed between Allahabad Safeda x ArkaKiran. Dhaliwal et al. (2003) reported that the maximum fruit set percentage of $92.42 \%$ was noted in Selection $4 / 12$ variety and minimum of $68.09 \%$ in Dharwad variety during winter season. Chatterjee et al. (1992) also observed $64.00 \%$ fruit retention in variety Red Fleshed and 60.00 $\%$ in Sardar.

Among different crosses maximum fruit length was recorded in Allahabad Safeda x Shweta $(51.25 \mathrm{~mm})$ followed by Allahabad Safeda x Arka Kiran (49.34 mm), Allahabad Safeda x Lalit $(48.15 \mathrm{~mm}$ ) and Allahabad Safeda x Purple Guava (43.50 $\mathrm{mm})$; however, maximum fruit width was observed in Allahabad Safeda x Shweta $(48.70 \mathrm{~mm})$ which was closely followed by Allahabad Safeda x Purple Guava (48.39 mm). Allahabad Safeda x Shweta and Allahabad Safeda x Purple Guava crosses had no

Table 1: Pollen germination percentage among different guava varieties

\begin{tabular}{ll}
\hline Varieties & Pollen germination $(\%)$ \\
\hline Allahabad Safeda & $87.33 \pm 0.70^{\mathrm{a}}$ \\
Lalit & $85.30 \pm 0.60^{\mathrm{a}}$ \\
Arka Kiran & $72.35 \pm 3.33^{\mathrm{b}}$ \\
Purple Guava & $83.59 \pm 1.37^{\mathrm{a}}$ \\
Shweta & $85.16 \pm 0.56^{\mathrm{a}}$ \\
S.E. Mean & 2.61 \\
LSD $(p \leq 0.05)$ & 6.02 \\
\hline
\end{tabular}

Means with the same letter are not significantly different (LSD, $p \leq 0.05)$. Each value represents treatment mean of three replicates $\pm S$.E.

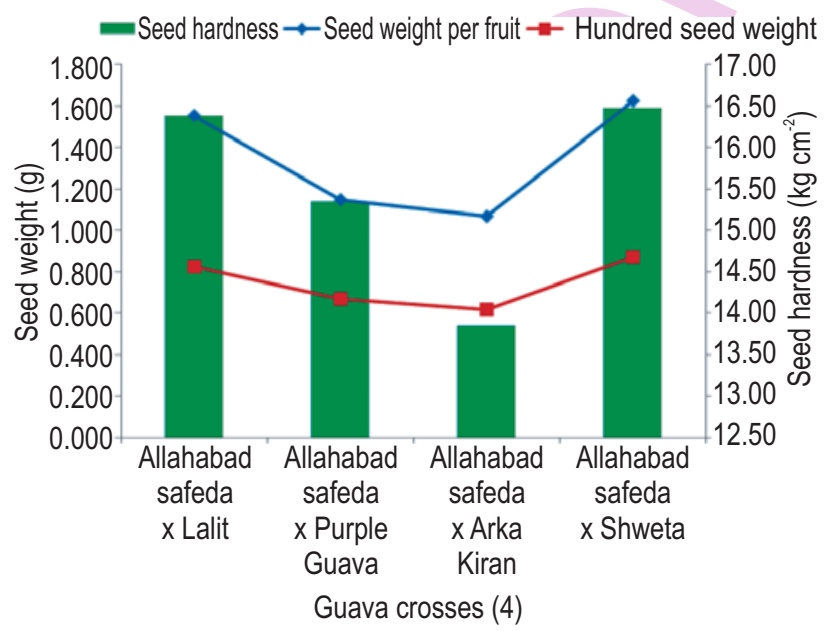

Fig. 1 : Comparative performance of seed hardness, seed weight per fruitand 100-seed weight in different guava combinations significant difference among them but both were significantly different from other crosses. Minimum fruit width of $45.70 \mathrm{~mm}$ was recorded in Allahabad Safeda $x$ Lalit followed by Allahabad Safeda $x$ Arka Kiran $(46.66 \mathrm{~mm})$. The data pertaining to fruit weight during rainy season crop of Allahabad Safeda $x$ Shweta had significantly higher fruit weight $(71.84 \mathrm{~g})$ than remaining crosses (Table 2). It was closely followed by Allahabad Safeda $x$ Arka Kiran (68.53 g), Allahabad Safeda x Lalit (66.24 g) and Allahabad Safeda x Purple Guava (64.32 g). Similarly, Aulakh (2005) also found that the average fruit weight was maximum in BarafKhana $(110 \mathrm{~g})$ and minimum in strawberry $(68 \mathrm{~g})$.

The fruit surface colour of various guava crosses; Allahabad Safeda x Lalit, Allahabad Safeda x Shweta, Allahabad Safeda x Purple Guava and Allahabad Safeda x Arka Kiran was light green colour at maturity during rainy season crop. The fruit flesh colour of Allahabad Safeda $x$ Lalit, Allahabad Safeda $x$ Shweta, Allahabad Safeda x Purple Guava and Allahabad Safeda xArka Kiran was observed to be cream colour at maturity.

The highest total soluble solid (7.45 ${ }^{\circ}$ Brix) content was obtained in Allahabad Safeda x Arka Kiran, which were significantly higher among the other evaluated crosses. Allahabad Safeda x Shweta had $7.42^{\circ}$ Brix total soluble solids and it was also significantly higher than all other crosses (Table 3). In rainy season, the lowest total soluble solids were recorded in Allahabad Safeda $x$ Lalit $\left(7.22{ }^{\circ}\right.$ Brix) followed by Allahabad Safeda x Purple Guava (7.32 ${ }^{\circ}$ Brix) and the lowest titratable acidity was recorded in Allahabad Safeda x Arka Kiran (0.222 \%), followed by Allahabad Safeda x Shweta ( $0.236 \%$ ) and the highest titratable acidity $(0.283 \%)$ was obtained in Allahabad Safeda $x$ Purple Guava, which was significantly higher among the evaluated crosses. Allahabad Safeda x Lalit had $0.245 \%$ titratable acidity and it was also significantly higher than all other crosses. The Allahabad Safeda x Purple Guava had significantly higher vitamin $\mathrm{C}$ (180.14 mg $100 \mathrm{~g}^{-1}$ fruit) content than remaining crosses. Adrees et al. (2010) concluded that maximum vitamin C $\left(220.4 \mathrm{mg} \mathrm{100g}^{-1}\right)$ and total sugars $(6.36 \%)$ were found in variety Hong Kong, TSS (11.87\%) in Sufaida. It was closely followed by Allahabad Safeda x Lalit (165.77 mg $100 \mathrm{~g}^{-1}$ fruit), Allahabad Safeda x Shweta (161.34 mg $100 \mathrm{~g}^{-1}$ fruit). Anupa et al. (2012) also observed the fruit of apple colour (R4P3-32) had a TSS of $15.38^{\circ} \mathrm{B}$ with moderate acidity $(0.27 \%)$ and ascorbic acid $(210.01$ $\left.\mathrm{mg} 100 \mathrm{~g}^{-1}\right)$.

Guava fruit have a pectin content that is causative to strengthen the tissues (Kumar et al., 2015). The pectin content ranged from $0.800 \%$ in Allahabad Safeda $x$ Shweta to $0.833 \%$ in Allahabad Safeda x Arka Kiran. Allahabad Safeda x Shweta $(0.800 \%)$ and Allahabad Safeda x Purple Guava (0.803 \%) crosses had no significant difference among them, but both were significantly different from other crosses (Table 3). The pectin percent, significantly decreased at maturity stages and fruit ripening in both seasons of study (Ahmed et al., 2013). 
Table 2: Fruit and seed characteristics of different guava cross combinations

\begin{tabular}{lllll}
\hline Varieties & Fruit length $(\mathrm{mm})$ & Fruit width $(\mathrm{mm})$ & Fruit weight (g) & Seed per fruit (no.) \\
\hline Allahabad Safeda x Lalit & $48.15 \pm 1.10^{\mathrm{b}}$ & $45.70 \pm 0.28^{\mathrm{c}}$ & $66.24 \pm 0.63^{\mathrm{bc}}$ & $190 \pm 0.88^{\mathrm{a}}$ \\
Allahabad Safeda x Purple Guava & $43.50 \pm 0.56^{\mathrm{c}}$ & $48.39 \pm 0.20^{\mathrm{a}}$ & $64.32 \pm 0.62^{\mathrm{c}}$ & $173 \pm 0.67^{\mathrm{c}}$ \\
Allahabad Safedax Arka Kiran & $49.34 \pm 0.63^{\mathrm{ab}}$ & $46.66 \pm 0.09^{\mathrm{b}}$ & $68.53 \pm 0.54^{\mathrm{b}}$ & $171 \pm 0.33^{\mathrm{d}}$ \\
Allahabad Safedax Shweta & $51.25 \pm 0.62^{\mathrm{a}}$ & $48.70 \pm 0.07^{\mathrm{a}}$ & $71.84 \pm 0.92^{\mathrm{a}}$ & $184 \pm 0.58^{\mathrm{b}}$ \\
S.E. Mean & 1.22 & 0.25 & 0.96 & 0.45 \\
LSD $(p \leq 0.05)$ & 2.98 & 0.60 & 2.36 & 1.10 \\
\hline
\end{tabular}

Means with same letter are not significantly different $(L S D, p \leq 0.05)$. Each value represents treatment mean of three replicates $\pm S . E$.

Table 3: Physico-chemical attributes of different guava cross combinations

\begin{tabular}{lllll}
\hline Varieties & TSS ('Brix) & Acidity (\%) & Vitamin C (mg 100 g ${ }^{-1}$ fruit) & Pectin content (\%) \\
\hline Allahabad Safedax Lalit & $7.22 \pm 0.007^{\mathrm{d}}$ & $0.245 \pm 0.008^{\mathrm{b}}$ & $165.77 \pm 2.43^{\mathrm{b}}$ & $0.817 \pm 0.020^{\mathrm{ab}}$ \\
Allahabad Safeda x Purple Guava & $7.32 \pm 0.006^{\mathrm{c}}$ & $0.283 \pm 0.006^{\mathrm{a}}$ & $180.14 \pm 6.34^{\mathrm{a}}$ & $0.803 \pm 0.023^{\mathrm{b}}$ \\
Allahabad Safedax Arka Kiran & $7.45 \pm 0.007^{\mathrm{a}}$ & $0.222 \pm 0.009^{\mathrm{d}}$ & $153.30 \pm 7.84^{\mathrm{c}}$ & $0.833 \pm 0.029^{\mathrm{a}}$ \\
Allahabad Safedax Shweta & $7.42 \pm 0.005^{\mathrm{b}}$ & $0.236 \pm 0.001^{\mathrm{c}}$ & $161.34 \pm 1.68^{\mathrm{bc}}$ & $0.800 \pm 0.032^{\mathrm{b}}$ \\
S.E. Mean & 0.004 & 0.001 & 4.29 & 0.008 \\
LSD $(p \leq 0.05)$ & 0.009 & 0.004 & 10.51 & 0.019 \\
\hline
\end{tabular}

Means with same letter are not significantly different $(L S D, p \leq 0.05)$. Each value represents treatment mean of three replicates $\pm S . E$.

Table 4: Vegetative characters of different $F_{1}$ hybrids of guava

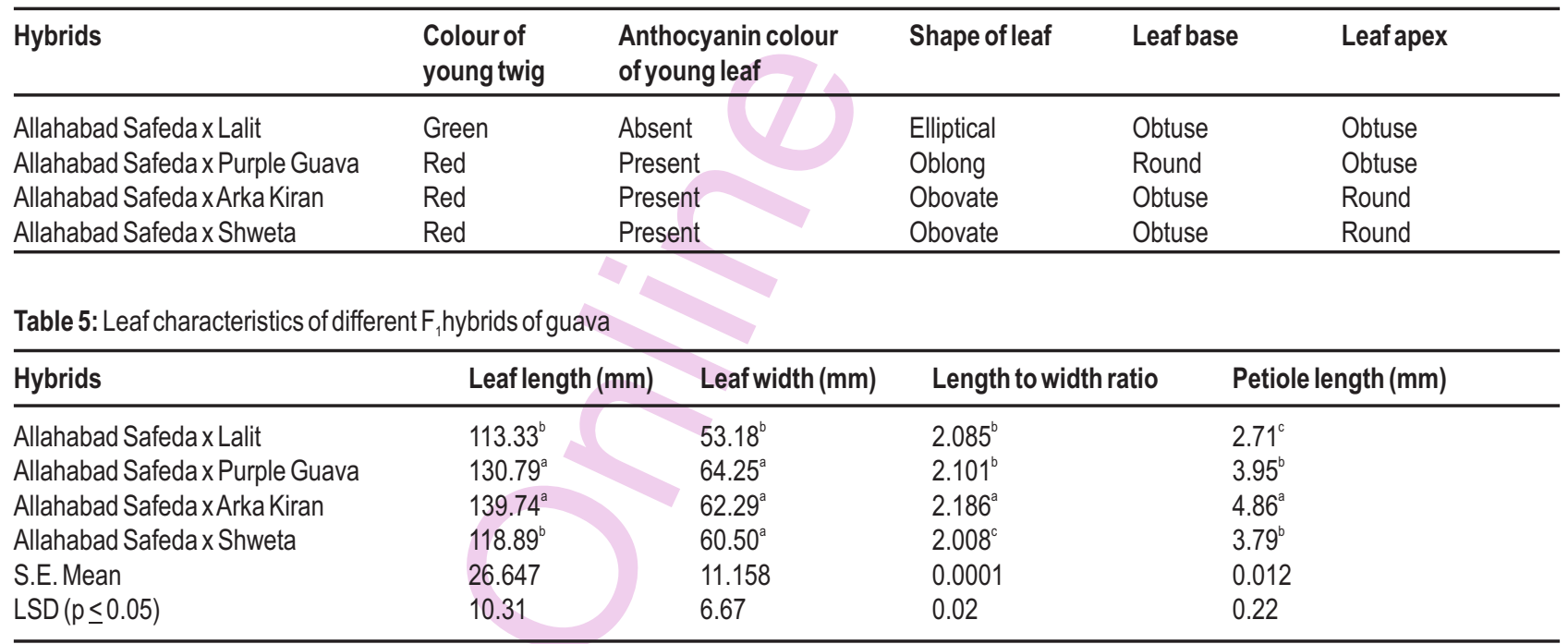

Means with same letter are not significantly different (LSD, $p \leq 0.05)$

Fruit quality in guava depends upon seed content of fruit and generally guava contains higher seed content when compared to other fruit crops. Breeding new varieties with low seed content is one of the major objectives in guava breeding, so in the present investigation, the data regarding seed number per fruit of different guava crosses revealed that the highest number of seeds per fruit (190) was obtained in Allahabad Safeda x Lalit, and Allahabad Safeda $\times$ Shweta had 184 seeds per fruit and was significantly higher than all other crosses (Table 2). In this season, the lowest number of seeds per fruit was recorded in Allahabad
Safeda x Arka Kiran (171) followed by Allahabad Safeda x Purple Guava (173). Marak et al. (2007) was also found that out of ten seedlings, A.C.Seln.6/10 noticed, the fruits of this selection had less number of seeds ( 142 seeds) and on the basis of fruit quality attributes A.C. Seln $6 / 10$ was found to be the best for less seeded commercial cultivation. Variation in seed weight per fruit ranged from $1.070 \mathrm{~g}$ in Allahabad Safeda $x$ Arka Kiran to $1.628 \mathrm{~g}$ in Allahabad Safeda $x$ Shweta. Significantly higher seed weight per fruit was recorded in Allahabad Safeda x Shweta $(1.628 \mathrm{~g})$, which was found at par with Allahabad Safeda x Lalit $(1.558 \mathrm{~g})$. 
Allahabad Safeda x Arka Kiran (1.070 g) and Allahabad Safeda x Purple Guava $(1.150 \mathrm{~g})$ crosses had no significant difference among them but both were significantly different from other crosses. The highest range of 100 -seed weight $(0.874 \mathrm{~g})$ was obtained in Allahabad Safeda x Shweta, which was significantly higher among the evaluated crosses. Allahabad Safeda $x$ Lalit had $0.827 \mathrm{~g} 100$-seed weight and it was also significantly higher than all other crosses. In this season, the lowest weight of 100seed weight was recorded in Allahabad Safeda x Arka Kiran $(0.616 \mathrm{~g})$. Babu et al. (2007) was also studied the seediness was

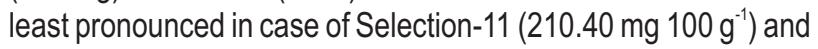
Selection-7 (192.50 mg $100 \mathrm{~g}^{-1}$ ) showed increased content of ascorbic acid.

The seed hardness governs fruit quality in guava, as soft seed is chosen over hard seeds. Breeding for soft seeded cultivars is one of the main objectives of guava breeding programmes and its association with other fruit characters. This trait during rainy season crop; Allahabad Safeda $x$ Shweta has significantly higher seed hardness $\left(16.48 \mathrm{~kg} \mathrm{~cm}^{-2}\right)$ than remaining crosses (Fig. 1). It was closely followed by Allahabad Safeda $x$ Lalit (16.39 kg cm$)^{-2}$ ), Allahabad Safeda x Purple Guava $(15.35 \mathrm{~kg}$ $\mathrm{cm}^{-2}$ ) and Allahabad Safeda xArka Kiran $\left(13.86 \mathrm{~kg} \mathrm{~cm}^{-2}\right)$. The seed size of Allahabad Safeda $x$ Lalit and Allahabad Safeda $x$ Shweta were bold at maturity.

A total of $398 F_{1}$ hybrids; Allahabad Safeda $x$ Lalit, Allahabad Safeda x Purle Guava, Allahabad Safeda x Arka Kiran and Allahabad Safeda $x$ Shweta of guava were developed involving one female (Allahabad Safeda) and four male parents (Lalit, Purple Guava, Arka Kiran and Shweta) with the objective to develop high yielding, better keeping quality, coloured skin and flesh and low/soft seeded fruits. The seed germination percentage and morphological parameters (only leaf) were recorded in different $F_{1}$ hybrids to distinguish among themselves.

High heterozygosity and numerous cross pollination are resulted in the existing variability in seedling populations from which promising varieties have been selected (Dinesh et al., 2010b). Seed germination is an estimate of the viability of a population of seeds; the highest seed germination percentage $(67.58 \%)$ was observed in Allahabad Safeda x Purple Guava hybrid, followed by Allahabad Safeda x Arka Kiran (53.34 \%) and Allahabad Safeda x Shweta (49.34 \%). However, the lowest seed germination percentage was (34.37\%) recorded in Allahabad Safedax Lalithybrid.

Variation in young twig colour was observed among different hybrids which varied from green to red. Red coloured young twigs were found in cross combination viz; Allahabad Safeda x Purple Guava, Allahabad Safeda x Arka Kiran and Allahabad Safeda $x$ Shweta. Anthocyanin colouration of young leaf was also present in these hybrids, whereas green coloured twigs were found in Allahabad Safeda x Lalit and the young leaves in this hybrid were also green due to absence of anthocyanin colouration (Table 4). Intensity of anthocyanin colouration in young leaves was observed to be strong in hybrids Allahabad Safeda x Purple Guava, Allahabad Safeda x Shweta and of weaker intensity in Allahabad Safeda $x$ Arka Kiran. Variation in leaf shape was observed among the obtained hybrids. Leaves were categorized according to different leaf shapes as elliptical in Allahabad Safeda x Lalit with obtuse leaf base and apex. Obovate leaves were observed in Allahabad Safeda $x$ Arka Kiran and Allahabad Safeda $x$ Shweta with obtuse leaf base and round leaf apex. However, oblong leaf shape was observed in Allahabad Safeda $x$ Purple Guava with round leaf base and obtuse leaf apex.

Leaf blade length ranged from a minimum value 113.33 $\mathrm{mm}$ in Allahabad Safeda x Lalit to a maximum value of $139.74 \mathrm{~mm}$ in Allahabad Safeda x Arka Kiran which was at par with Allahabad Safeda x Purple Guava with the value $130.79 \mathrm{~mm}$. Hybrids Allahabad Safeda $x$ Lalit and Allahabad Safeda $x$ Shweta were at par among each other and Allahabad Safeda $x$ Lalit had least value for leaf length (Table 5). (Singh et al., 2016) also observed a significant variation in leaf length among different guava varieties ranging from $101.89 \mathrm{~mm}$ in Lalit to $151.27 \mathrm{~mm}$ in Punjab Pink, while, maximum leaf blade width was recorded in L-49 variety $(65.54 \mathrm{~mm})$. Statistically significant variation for leaf blade width values were observed among tested hybrids. Highest for leaf blade width $(64.25 \mathrm{~mm})$ was observed in Allahabad Safeda $x$ Purple Guava, which was statistically at par with Allahabad Safeda $x$ Arka Kiran and Allahabad Safeda $x$ Shweta with the values 62.29 and $60.50 \mathrm{~mm}$, respectively whereas least average value for the same trait was recorded in Allahabad Safeda x Lalit having a value of $53.18 \mathrm{~mm}$. In different hybrids, variation in leaf length to width ratio was observed varying from a minimum value of 2.008 in Allahabad Safeda x Shweta to the tune of 2.186 in Allahabad Safeda $x$ Arka Kiran and these were significantly different from each other. Allahabad Safeda $x$ Lalit (2.085) was found to be statistically at par (2.101) with Allahabad Safeda $x$ Purple Guava.

Petiole length among different hybrids also varied significantly with maximum $(4.86 \mathrm{~mm})$ value recorded in Allahabad Safeda x Arka Kiran and minimum $(2.71 \mathrm{~mm})$ in Allahabad Safeda $x$ Lalit. With respect to petiole length, hybrid Allahabad Safeda $x$ Arka Kiran differed significantly from all the hybrids and was followed by Allahabad Safeda x Purple Guava and Allahabad Safeda x Shweta with the values 3.95 and 3.79 $\mathrm{mm}$, respectively and these hybrids were statistically at par among each other. Among all the hybrids, green midrib colour on lower surface of leaf was observed in Allahabad Safeda $x$ Lalit and Allahabad Safeda x Arka Kiran. Red midrib colour on lower surface of leaf was observed in Allahabad Safeda x Purple Guava and Allahabad Safeda x Shweta. Likewise, Boora et al. (2012) obtained a potential hybrid Punjab Pink a cross between Portugal 


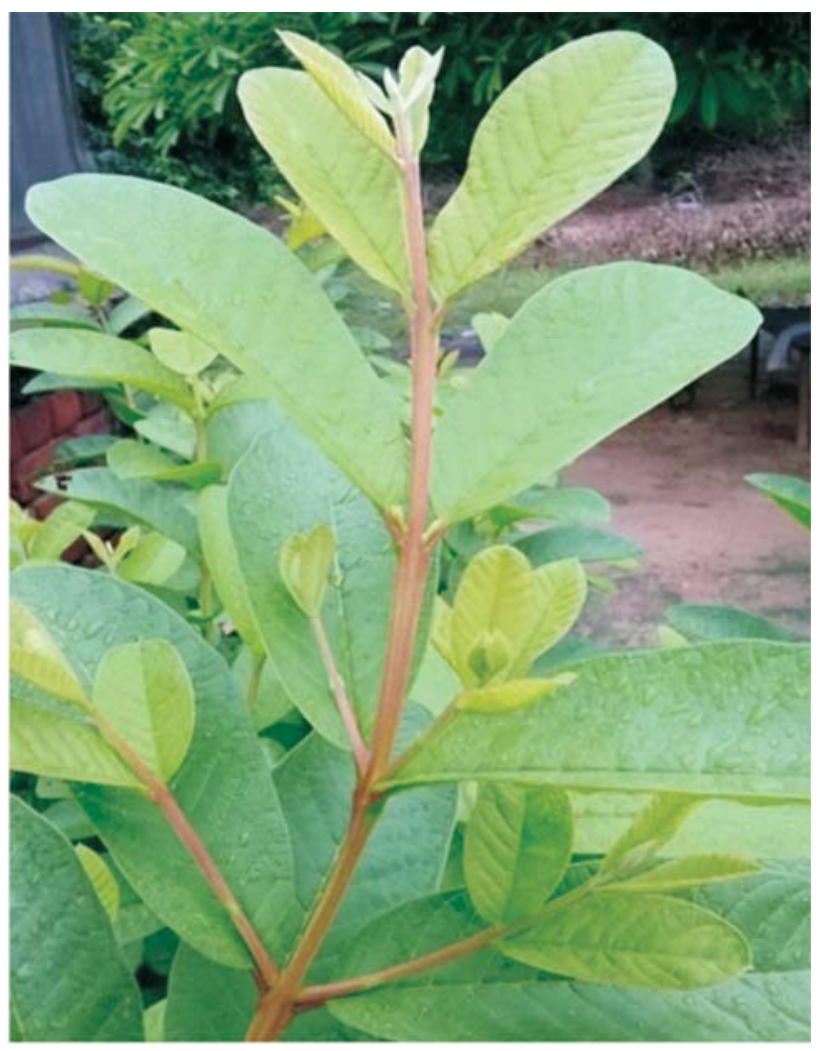

(A) Allahabad Safeda x Arka Kiran

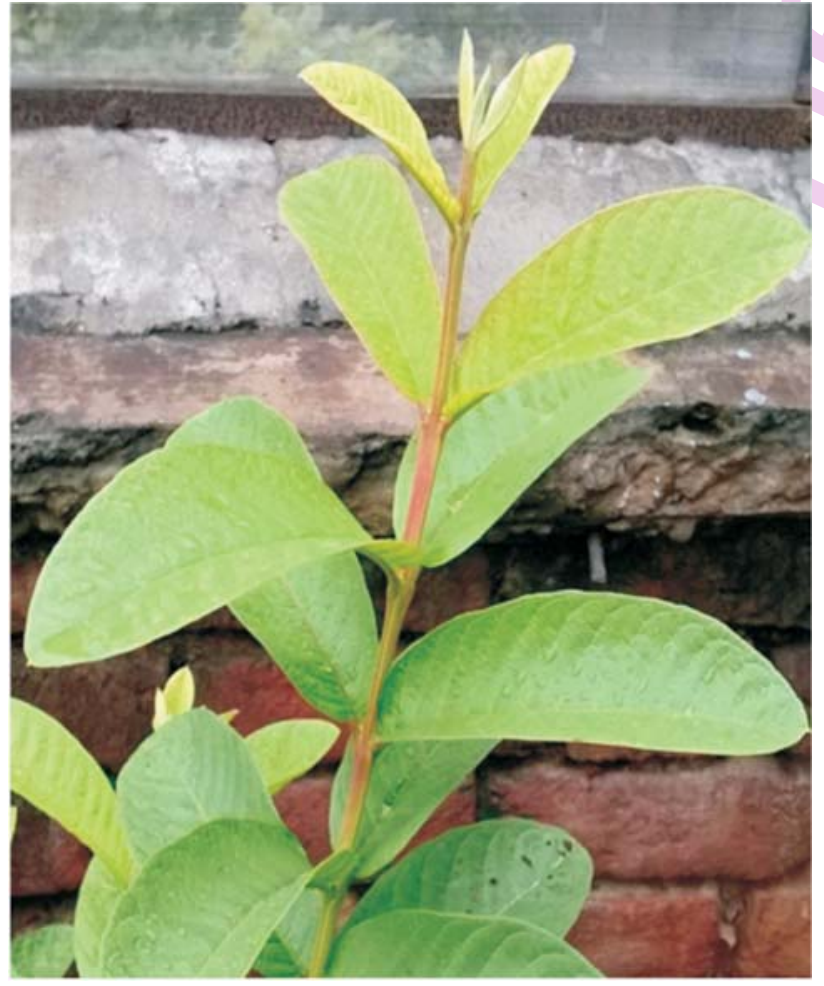

(C) Allahabad Safeda x Lalit

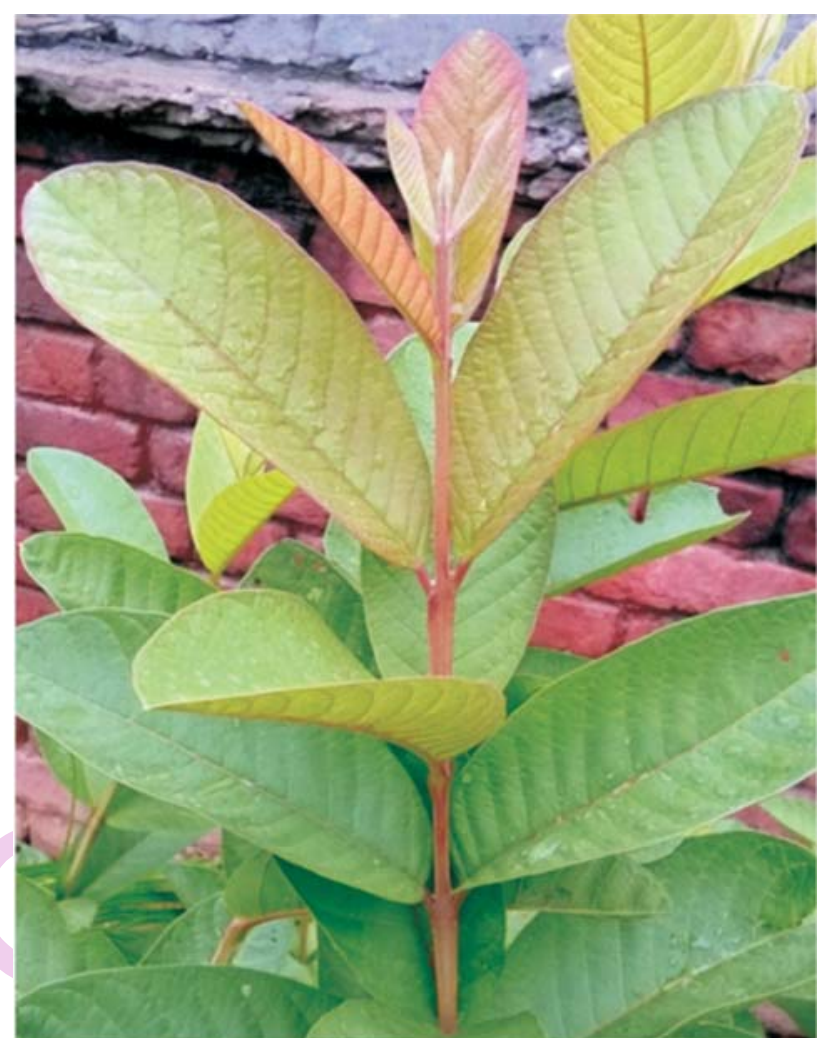

(B) Allahabad Safeda x Purple Guava

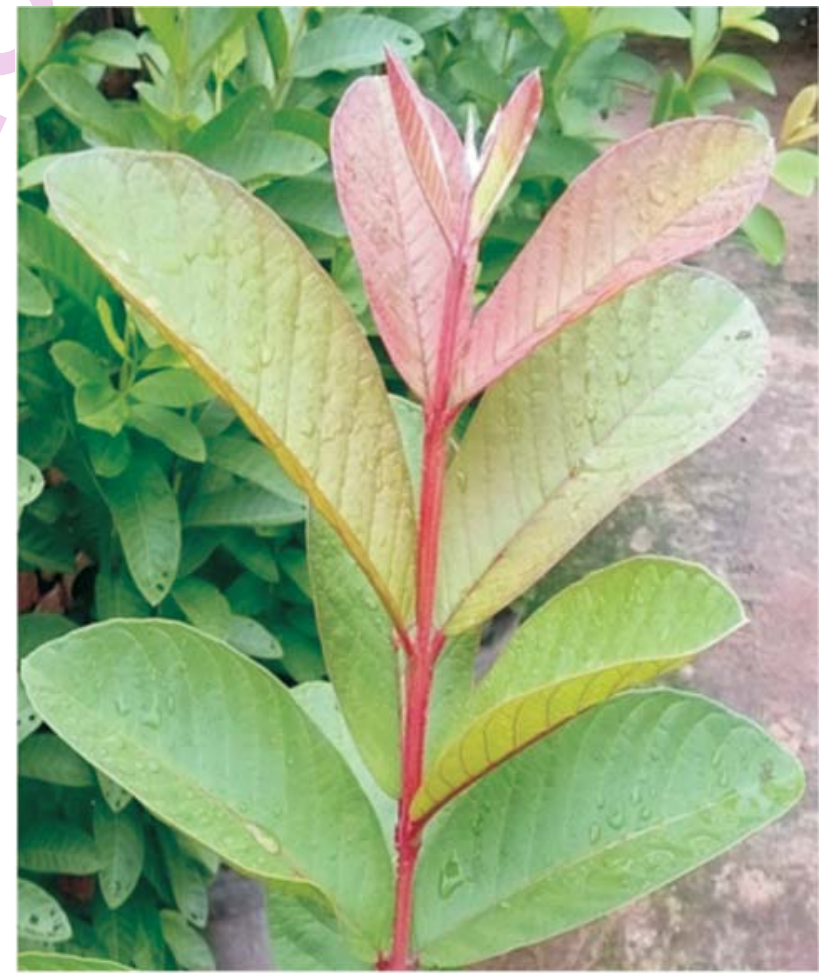

(D) Allahabad Safeda x Shweta

Fig. 2 : Colour of young twig and anthocyanin pigmentation of young leaf in different guava F1 hybrids 
XL-49 = F, XApple Colour. Patel et al. (2011) also made nineteen crosses, the seedlings of fourteen crosses were well established in the field and six hybrids flowered and fruits were harvested and evaluated for fruit characteristics. The fruit of hybrid "Anand Selection (Red) x Exotica" was large in size, had pleasant flavour and high TSS with soft seeds.

To conclude, the commercial guava variety Allahabad Safeda was crossed with potential varieties having traits of commerce such as coloured skin/flesh and with soft/low seed number. The potential varieties included Lalit, Purple Guava, Arka Kiran and Shewta were used as male parents. The obtained hybrid seedlings have been planted in the field. The putative hybrids, thus generated have shown variability in morphological traits and indicate hybridity. Thus in present study, appropriate hybridization methodology has been work out to obtain guava hybrids. The coloured hybrids are likely to be the outcome of the present study which would help in boosting guava cultivation in the northern region of country.

\section{References}

Adrees, M., M. Younis, U. Farooq and K. Hussain: Nutritional quality evaluation of different guava varieties. Pak. J. Agri. Sci., 47, 1-4 (2010)

Ahmed, W. A.: Evaluation of some varieties of guava trees grown under Alexandria Governorate condition II compositional changes during fruit ripening. J. World Appli. Sci., 28, 750-58 (2013).

Anupa, T., S. Jaganath, R. Girisha and A.P. Mallikarjunagowda: Studies on qualitative characteristics in different varieties of apple colour guava (Psidium guajava L.). Ind. J. Agric. Env. Biotech., 5, 109-112 (2012).

AOAC: Official Methods of Analysis, $18^{\text {th }} \mathrm{Edn}$., Association of Official Analytical Chemist, Washington DC (2005).

Aulakh, P.S.: Performance of different guava cultivars under the arid irrigated condition of Punjab. Prog. Hort., 37, 328-330 (2005).

Babu, K.D., R.K. Patel and D.S. Yadav: Comparative evaluation of guava selections under north eastern region of India. Acta Hort., 735, 99104 (2007).

Boora, R.S.: Improvement in guava- A review. Agri.Revi., 33, 341-49 (2012).

Chatterjee, D., U.P. Singh, S. Thakur and R. Kumar: Anote on the bearing habits of guava (Psidium guajava L.). Har. J. Hort. Sci., 21, 67-71 (1992).
Coser, S.M., M.M.P. Fontes and M.F.S. Ferreira: Assessment of pollen viability in guava varieties. Acta Hort., 959, 56 (2012).

Dhaliwal, G.S. and R. Singla: Studies on the time of anthesis and dehiscence in different varieties of guava in winter and rainy season crops. Ind. J. Hort., 59, 157-161 (2002).

Dhaliwal, G.S. and R. Singla: Pollen, pollination and fruit set studies in different genotypes of guava in winter and rainy season crops under Ludhiana conditions. Har. J. Hort. Sci., 32, 159-162 (2003).

Dinesh, M.R. and C. Vasugi: Guava improvement in India and future needs. J. Hort. Sci., 5, 94-108 (2010a).

Dinesh, M.R. and C. Vasugi: Phenotypic and genotypic variations in fruit characteristics of guava (Psidium guajava L.) Ind. J. Agri. Sci., 80, 62-63 (2010b).

Kumar, S., N.K. Jain, K.C. Sharma, R. Paswan, B.K. Mishra, R. Srinivasan and S. Mandhania: Optimization, purification and characterization of pectinases from pectinolytic strain, Aspergillus foetidus MTCC 10559. J. Environ. Biol., 36, 483-489 (2015).

Landrum, L.R., W.D. Clark, W.P. Sharp and J. Brendecke: Hybridization between Psidium guajava and P. guineense (Myrtaceae). Eco. Bot., 49, 153-161 (1995).

Marak, J.K. and G.K. Mukunda: Studies on the performance of open pollinated seedling progenies of guava cv. 'Apple Colour'. Acta Hort., 735, 79-84(2007).

Negi, S.S. and S. Rajan: Improvement of guava through breeding. Acta Hort., 735, 31-38 (2007)

Patel, D.A., H.C. Patel, S.N. Saravaiya, P.B. Koladiya and B.N. Patel: Development of hybrids in guava. Int. J. Plant Sci.,6, 237-239 (2011).

Pommer, C.V.: Guava world-wide breeding: major techniques and cultivars and future challenges. Acta Hort., 959, 81-88 (2012).

Rodriguez, N.N.M., G.A. Fermin, J. Valdes-Infante, B. Velasquezi, D. Rivero, F. Martinez, J. Rodriguez and W. Rohde: Illustrated descriptors for guava (Psidium guajava L.). Acta Hort., 849, 103110 (2010).

Santos, C. and L.C. Correa: Antioxidant and biochemical content in Brazilian guava germplasm with white, red and pink pulps. Acta Hort., 959, 125-130 (2012).

Singh, D., M.I.S. Gill and N.K. Arora: Morphological characterization of promising guava (Psidium guajava L.) varieties under subtropical humid conditions of north india. The Bioscan, 11, 681-685 (2016).

Usman, M., W.A. Samad, B. Fatima and M.H. Shah: Pollen parent enhances fruit size and quality in intervarietal crosses in guava (Psidium guajava). Int. J. Agri. Bio., 15, 125-129 (2013). 